\title{
KERJASAMA KEIMIGRASIAN DALAM ASEAN DAN ASEM (Immigration Cooperation within ASEAN and ASEM)
}

\author{
Alfian Zana Lazuardi (1), Deni Meidistira Adityatama ${ }^{(2)}$, Yaser Arya Saputra ${ }^{(3)}$ \\ 1,2,3 Politeknik Imigrasi Badan Pengembangan Sumber Daya Manusia Hukum dan HAM RI. Indonesia
} Email : daredavul@gmail.com

\begin{abstract}
ABSTRAK
Penelitian ini mencoba untuk mengamati kerjasama keimigrasian khususnya kerjasama keimigrasian dalam ASEAN dan ASEM. Tujuan dilakukan penelitian ini adalah untuk mengetahui dan memahami implementasi dan bentuk kerjasama keimigrasian dalam ASEAN dan ASEM. Digunakan metode kualitatif dalam penulisan ini, data didapat melalui studi kepustakaan kemudian dikumpulkan dan dianalisis untuk disajikan dalam bentuk deskriptif secara sistematis. Dari penelurusan data sekunder, didapat hasil salah satu bentuk kerjasama ASEAN dalam keimigrasian adalah dibentuknya kebijakan bebas visa atau ASEAN Framework Agreement on Visa Exemption, sementara pada pembahasan kerjasama keimigrasian ASEM membahas mengenai lembaga bernama The Asia-Europe Foundation (ASEF) yang berkaitan dengan keimigrasian. Dalam penerapan kerjasama keimigrasian ASEAN tersebut disatu sisi memberi banyak manfaat namun disisi lain juga tak dapat dihindari adanya kerugian dan permasalahan, sementara bentuk kerjasama keimigrasian ASEM terlihat berjalan baik karena tetap mempertahankan hak-hak para migran dalam hal keimigrasian, salah satu yang dibahas disini adalah pemberian jaminan kesehatan.
\end{abstract}

Kata Kunci: Keimigrasian, ASEAN, ASEM

\section{ABSTRACT}

This research tries to observe cooperation on immigration, especially cooperation on immigration within ASEAN and ASEM. The purpose of this research is to know and understand the implementation and forms of immigration cooperation in ASEAN and ASEM. Qualitative methods are used in this paper, data are obtained through literature study and then collected and analyzed to be presented in a systematic descriptive form. From secondary data research, it was found that one form of ASEAN cooperation in immigration was the formation of a visa-free policy or the ASEAN Framework Agreement on Visa Exemption, while at the discussion on immigration cooperation ASEM discussed an institution called The Asia-Europe Foundation (ASEF) which deals with immigration. In the implementation of ASEAN immigration cooperation on the one hand it provides many benefits but on the other hand it is also inevitable that there are losses and problems, while the form of ASEM immigration cooperation looks good because it maintains the rights of migrans in terms of immigration, one of which is discussed here is giving health insurance.

Keywords : Immigration, ASEAN, ASEM

\section{PENDAHULUAN}

Latar Belakang

Pada dasarnya, menurut Soerjono Sokeanto kerjasama dimaksudkan sebagai usaha yang dilakukan oleh perorangan atau kelompok secara bersama-sama guna mencapai tujuan tertentu, sementara Muhammad Jafar Hafsah mengartikan 
kerjasama sebagai suatu strategi bisnis yang dilakukan oleh dua pihak atau lebih, didalam rentang waku tertentu dan bertujuan untuk mencapai keuntungan bersama dengan memegang prinsip saling membutuhkan juga saling membesarkan, dan tujuan utama kerjasama adalah win win solution. Sementara itu, UU No. 6/2011 pada pasal 1 angka 1 memberikan pengertian keimigrasian sebagai hal ihwal lalu lintas orang yang keluar dan masuk wilayah Indonesia serta pengawasannya dalam rangka menjaga tegaknya kedaulatan Negara. Dari pengertian tersebut, terdapat batasan dua kelompok tugas yang menjadi tanggungjawab institusi keimigrasian yakni pelayanan lalu lintas orang dan pengawasan terhadap orang asing. Sementara itu, kerjasama keimigrasian didefinisikan sebagai sebuah perikatan diantara dua lembaga atau lebih dalam menyelesaikan permasalahan maupun yang masih menjadi potensi permasalahan keimigrasian dan pelaksanaannya. Direktorat Jenderal Imigrasi sendiri membangun Border Control Management untuk kemudian dikembangkan sebagai bagian dari Sistem Informasi dan Manajemen Keimigrasian untuk mendukung tugas pokok dan fungsi dalam hal perekaman data dan pemeriksaan keimigrasian tentang lalu lintas orang yang keluar masuk dari dan ke wilayah Indonesia. Tujuan lainnya adalah untuk mencapai kesetaraan alur kerja dalam hal kepastian dan kemudahan untuk pelaksana perekaman data dan pemeriksaan keimigrasian yang ada di Tempat Pemeriksaan Imigrasi.

Setidaknya terdapat dua bentuk atau produk kerjasama keimigrasian yaitu kerjasama tertulis dan kerjasama aksi, dimana kerjasama tertulis terdiri dari nota kesepahaman dan juga perjanjian kerjasama, sementara kerjasama aksi misalnya misi diplomatik kenegaraan dan misi diplomatik organisator. Dari beberapa bentuk kerjasama keimigrasian tersebut, penulis tertarik untuk mengetahui bentuk kerjasam keimigrasian yang dilakukan ASEAN dan juga ASEM sehingga dipilih penelitian dengan judul Kerjasama Keimigrasian dalam ASEAN dan ASEM.

\section{Rumusan Masalah}

Atas latar belakang yang telah dipaparkan, didapat rumusan masalah yaitu seperti apa bentuk kerjasama keimigrasian yang terjadi dalam ASEAN dan ASEM?

\section{Tujuan}

Adapun tujuan dilakukannya penelitian adalah untuk mengetahui implementasi dan bentuk kerjasama keimigrasian dalam ASEAN dan ASEM.

\section{Metode Penelitian}

1. Pendekatan $\rightarrow$ kualitatif, yakni bertujuan untuk memperoleh pengertian serta pemahaman mengenai suatu peristiwa ataupun perilaku manusia didalam suatu organisasi maupun institusi.

2. Metode Pengumpulan Data. Untuk mendukung jalannya penelitian, dilakukan pengumpulan data dengan metode studi kepustakaan yang artinya menggunakan data sekunder, bukan data yang didapat melalui penelitian secara langsung di lapangan. Adapun data sekunder yang dimaksud terdiri dari buku, jurnal, peraturan perundang-undangan, serta artikel terkait yang menunjang penelitian.

3. Teknik Analisa Data. Setelah data terkumpul, kemudian dilakukan analisa dan dikaitkan dengan teori yang ada, disajikan secara deskriptif dalam bentuk uraian yang sistematis dan logis.

\section{PEMBAHASAN}

ASEAN Framework Agreement on Visa Exemption sebagai bentuk kerjasama keimigrasian ASEAN

ASEAN memaknai lapangan kerja, perkembangan kualitas tenaga kerja serta penyediaan keamanan sosial bagi para pekerjanya sebagai suatu hal yang penting. Namun memang pada faktanya, tenaga kerja asing di ASEAN mendapatkan akses yang 
amat kecil dalam hal keamanan jalur imigrasi seperti penentuan tariff yang terlalu tinggi disamping honor yang rendah, kekerasan pada pekerja, waktu bekerja yang cukup lama, trafficking, kondisi pekerjaan yang mengeksploitasi, hingga tak dibayarkannya gaji. Di tahun 1995, ASEAN menandatangani kesepakatan kerjasama yang disebut ASEAN Framework Agreement on Services atau AFAS yang mengatur mengenai liberalisasi perdagangan dibidang jasa dalam ASEAN, dalam AFAS juga membahas mengenai isu migrasi tenaga kerja di ASEAN. Sementara itu, mengenai imigrasi yang berkaitan dengan tenaga kerja bebas dalam MEA disepakati oleh ASEAN dalam ASEAN MNP atau ASEAN Agreement on the Movement of Natural Persons.

Dalam hal kerjasama keimigrasian, ASEAN seringkali melakukan pertemuan rutin berkaitan dengan berbagai hal soal keimigrasian di ASEAN, misalnya pada tahun 2017 pembahasan dalam pertemuan tahunan itu adalah permasalahan perlintasan serta permasalahan di Tempat Pemeriksaan Imigrasi utama pada masing-masing Negara anggota ASEAN, selain itu dibahas pula mengenai fenomena migrasi illegal dan apa peran komunitas imigrasi dalam mendukung kampanye anti-terorisme beserta pencegahannya, terlebih hal tersebut menjadi topik bahasan yang mengandung semangat saling bertukar informasi sesama Negara ASEAN.

ASEAN bekerjasama dibidang imigrasi dan kekonsuleran dengan perjanjian kerangka ASEAN bebas visa (ASEAN Framework Agreement on Visa Exemption) yang ditandatangani pada tanggal 25 Juli 2006 pada AMM Ke-39 di Kuala Lumpur. Perjanjian tersebut dibuat guna mendukung pencapaian ASEAN Economic Community melalui perjalanan intra ASEAN dan juga kontak perorangan. Dalam Perpres No. 69/2015 juga diatur mengenai bebas visa kunjungan dalam pasal 4 yang member kebebasan bagi Negara untuk ijin tinggal selama 30 hari. Ada kemungkinan dikeluarkannya kebijakan bebas visa adalah untuk peningkatan pembangunan ekonomi melalui Masyarakat Ekonomi Asean akan bertentangan dengan Pasal 8 UU No.6/2011 tentang Keimigrasian yang menganut konsep selective policy.

Akibat kebijakan ini, industri pariwisata berkembang pesat karena pembebasan visa cukup membuat jumlah wisatawan meningkat secara signifikan. Di Indonesia sendiri, Menteri Pariwisata Arief Yahya memperkirakan adanya peningkatan jumlah kunjungan wisatawan sebanyak satu juta pertahund an pemauskan devisa sebsar 1 miliar dollar akibat adanya kebijakan bebas visa. Setidaknya terdapat tiga alasan atau landasan mengapa kebijakan pembebasan visa diterapkan, yakni :

1) Sebagai tindak lanjut dari ASEAN AFTA, dimana saat itu AFTA belum dapat dilaksanakan secara signifikan mengingat terhambatnya distribusi barang di kawasan Asia Tenggara oleh pengawasan perbatasan, jadi tujuan kebijakan pembebasan visa tidak lain adalah untuk mengatasi hambatan perdagangan.

2) Menyelesaikan masalah dalam integrasi ASEAN. ASEAN seringkali mendapatkan kritik sebagai organisasi regional yang tak mampu mengintegtrasikan Negara-negara anggota ASEAN, sehingga kebijakan pembebasan visa ini diformalkan sebagai kebijakan untuk menjawab kritik yang ada.

3) Pemerintah Negara ASEAN menginginkan adanya kenaikan jumlah wisatawan yang dating, karena hingga tahun 200-an, jumlah wisatawan di Negara-negara ASEAN tidak pernah melebihi 10 juta wisatawan.

Disatu sisi, skema ASEAN Framework Agreement on Visa Exemption menjadi langkah besar untuk mencapai cita-cita integrasi ASEAN secara menyeluruh, yakni integrasi keamanan dan aspek politik, serta ekonomi dan sosial budaya masyarakat. Adanya regulasi bebas visa ini memang menjadi solusi atas keresahan hambatan 
administratif yang selama ini cukup menyulitkan warga Negara ASEAN ketika bepergian dalam kawasan ASEAN. Namun ternyata, disisi lain regulasi ini dapat berdapak negatif pada keamanan Negara anggotanya, terlebih ketika dikaitkan dengan munculnya cara pandang baru dalam hal pandangan keamanan pasca perang dingin karena bentuk ancamannya bukan lagi sekadar ancaman tradisional melainkan berkembang ke arah ancaman nontradisional atau nonmiliter, seperti yang terlihat dengan semakin maraknya ancaman dalam kejahatan lintas batas. Beberapa Negara anggota ASEAN turut menanggapi kebijakan bebas visa dengan cara memperkuat hubungan imigrasi bilateral, diantaranya perjanjian pembebasan visa antara Myanmar dan Thailand yang ditandatangani tahun 2013, atau Indonesia dengan Myanmar tahun 2014 yang bertujuan memfasilitasi arus wisatawan kedua negara. Sudah banyak Negara ASEAN yang mengajukan kebijakan bebas visa di wilayahnya masing-masing untuk akses gratis bagi orang asing dari Negara maju. Misalnya Thailand yang memberlakukan pembebasan visa bagi 55 negara, Brunei, Myanmar dan Kamboja yang diberi hak istimewa selama 14 hari, sementara warga Negara dari anggota ASEAN lainnya bebas tinggal 30 hari tanpa visa. Negara lain sepeti Malaysia, Indonesia, Singapura, Vietnam dan Thailand memberikan visa gratis masingmasing untuk 63, 73, 25, 24 dan 141 negara.

Indonesia yang juga turut menerapkan kebijakan bebas visa memberikan dasar hukum mulai tahun 2003 hingga tahun 2016 yang terdiri dari :

1. Keputusan Presiden Nomor 18 tahun 2003 tentang Bebas Visa Kunjungan Singkat;

2. Perpres RI No. $16 / 2008$ tentang Perubahan Kedua atas Keputusan Presiden No. 18/2003 tentang Bebas Visa Kunjungan Singkat;

3. Perpres RI No, 43/2011 tentang Perubahan Ketiga atas Kepres No. 18/2003 tentang Bebas Visa Kunjungan Singkat;
4. Perpres RI no, 69/2015 tentang Bebas Visa Kunjungan;

5. Perpres No. 104/2015 tentang Perubahan atas Perpres No. 69/2015 tentang Bebas Visa Kunjungan;

6. Perpres RI No. 21/2016 tentang Bebas Visa Kunjungan.

Pertimbangan Indonesia dalam mengeluarkan beberapa Perpres adalah dalam rangka meningkatkan hubungan antara Republik Indonesia dengan negara lain, perlu diberikan akses ke wilayah Negara Kesatuan Republik Indonesia bagi warga negara asing dari negara tersebut, pemerintah daerah administrasi khusus suatu negara, dan entitas tertentu. Berupa pembebasan kewajiban mendapatkan visa kunjungan, dengan pertimbangan timbal balik dan manfaat; selain itu untuk memberikan manfaat lebih dalam perekonmian pada umumnya, khususnya peningkatan jumlah kunjungan wisatawan mancangera. Tujuannya tak lain untuk meperbaiki kinerja neraca perdagangan dan jasa yang selama ini sudah berjalan secara dominan.

Kebijakan bebas visa memang menjadi salah satu cara termudah meningkatkan wisatawan mancanegara yang masuk ke Indonesia. Indonesia telah mengalami peningkatan kedatangan orang asing secara signifikan, dimana tercatat pada tahun 2015 sebanyak 16.994 .858 orang datang dan 4.930.716 diantaranya menggunakan bebas visa, kemudian di tahun 2016 periode Januari hingga Februari, kedatangan orang asing sebanyak 2.671.218 yang mana hampir 50\% diantaranya pengguna bebas visa, hal ini sudah menjadi bukti banyaknya orang asing yang menggunakan kebijakan bebas visa ini dalam kurun waktu 2 bulan di tahun 2016. Tak hanya sampai 2016, di tahun 2017 juga terjadi peningkatan jumlah wisatawan mancanegara yang dating ke Indonesia, seperti yang terlihat pada gambar dibawah 


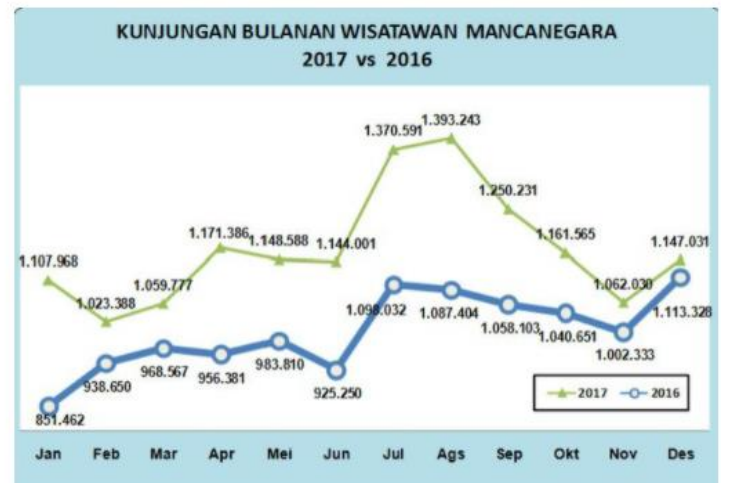

Sumber: Erdian, 2018.

Namun memang dengan adanya peningkatan kedatangan wisatawan, hal ini juga menjadikan potensi peningkatan pelanggaran keimigrasian Negara-negara penerima bebas visa secara signifikan, seperti yang terlihat pada tabel berikut

Tabel 1. Jumlah Pelanggaran Keimigrasian Periode Januari-Juli 2016

\begin{tabular}{|l|c|c|}
\hline No & $\begin{array}{c}\text { Nama Negara } \\
\text { Asal }\end{array}$ & $\begin{array}{c}\text { Jlm } \\
\text { Pelanggaran }\end{array}$ \\
\hline 1 & Tiongkok & 1180 \\
\hline 2 & Aganistan & 411 \\
\hline 3 & Bangladesh & 172 \\
\hline 4 & Filipina & 151 \\
\hline 5 & Irak & 127 \\
\hline
\end{tabular}

Sumber: Jazuli, 2016

Lebih luas, permasalahan lain yang timbul akibat kebijakan bebas visa kunjungan yaitu adanya peningkatan pelanggatan izin tinggal warga Negara asing, lapangan pekerjaan di Indonesia menyempit, tenaga kerja asing illegal bertambah banyak karena memanfaatkan bebas visa kunjungan, serta semakin terbuka luas pintu masuk untuk jaringan narkotika dan juga terorisme kedalam wilayah Indonesia. Disinilah peran pemerintah dibutuhkan untuk bersikap tegas karena permasalahan tersebut akan dapat mengancam kedaulatan negara.

\section{Kerjasama Keimigrasian ASEM}

Asia Europe Meeting atau biasa disingkat ASEM didirikan pada tahun 1996 di Bangkok yang hingga saat ini memiliki 53 mitra dari 30 negara Eropa, 21 negara Asia
Sekretariat ASEAN, dan Uni Eropa. Dalam bekerjasama, sifat kerjasama ASEM adalah informal, evolutionary, non-binding dan multi-deminsional dan berfokus pada tiga pilar kerjasama yakni ekonomi, politik dan social-budaya. ASEM yang berdiri tahun 1996 sudah mulai menjadi perwakilan proses penting dialog dan kerja sama diantara Negara-negara Eropa dan Asia yang mempertemukan 53 mitra, termasuk Uni Eropa, Negara anggotanya, ASEAN beserta sekretariatnya, dan Negara-negara lain dari dua benua. Sebagian besar pembahasan dalam dialog ASEM adalah pilar politik dan pertukaran tentang migrasi internasional. Mekanisme kerja ASEM bermuara pada Kepala Pemerintahan ASEM dalam format Konferensi Tingkat Tinggi (KTT) yang dilangsungkan dua tahun sekali. Dibawah KTT ASEM, pertemuan Menteri Luar Negeri ASEM dilangsungkan dua tahun sekali dan berselang-seling dengan jadwal KTT ASEM. Adapun materi yang dibahas pada KTT ASEM berkaitan dengan isu-isu internasional, regional hingga kasus-kasus tertentu yang masih berkaitan dengan politis dan memberi dampak besar pada kepentingan stabilitas perdamaian, keamanan dan kesejahteraan global.

Sejauh ini, ASEM telah menyelenggarakan sebanyak 13 konferensi yang berisi diskusi terkait pengendalian migrasi dan pengelolaan arus migrasi, sementara kerjasama dalam pengelolaan perbatasan migrasi diatur dalam berbagai program subregional UE-ASEAN, yang mana para pemimpinnya telah mengembangkan instrumen lain lebih lanjut untuk menangani mobilitas manusia, pengalaman kebijakan yang dapat berfungsi memperluas agenda ASEM tentang arus lintas batas manusia. Di tahun 2016 yaitu saat KTT ASEM yang ke-11, para pemimpinnya menggariskan visi mengenai konektivitas yang meliputi sinergi progam konektivitas yang ada pada kedua kawasan, beserta pembahasan lain termasuk pembahasan mengenai harmonisasi peraturan imigrasi dan 
cukai guna kelancaran people's mobility. Memang sejak tahun 2003, ASEM turut berpartisipasi dalam hal pertukaran tentang migrasi internasional dibawah Konferensi ASEM dengan ruang lingkup penguatan hubungan diantara otoritas imigrasi anggota dan juga pertukaran izin informasi serta praktik yang baik di bidang migrasi internasional. Sementara kerjasama pada manajemen perbatasan dan aspek keamanan yang berkaitan dengan keimigrasian hanya satu dimensi dari tata kelola migrasi, selebihnya instrument kebijakan lain dirancang oleh ASEM untuk meningkatkan kerjasama dalam konektivitas antar individu. Lalu ditahun sebelumnya 2002, ASEM telah membahas topik migrasi setelah Konferensi Tingkat menteri ASEM tentang Kerjasama untuk Pengelolaan Arus Migrasi Eropa dan Asia, dan sejak Maret 2003 telah rutin dilakukan Konferensi ASEM Direktur Jenderal Imigrasi dan Manajemen Arus Migrasi.

Perlindungan hak-hak migran telah menjadi kebijakan yang berulang yang dibahas pada dialog ASEM, dimana saat KTT ke-9, para pemimpin ASEM berkomitmen untuk memberikan kepastian hak asasi manusia para migran beserta keluarganya, termasuk juga pekerja migran ketika menghadapi kesulitan ekonomi serta untuk memperkuat mekanisme kerjasama internasional dan menggarisbawahi kebutuhan untuk mengidentifikasi cara maksimal yang sesuai untuk manfaat pembangunan sekaligus menjawab tantangan yang timbul karena migrasi.

Terdapat sebuah lembaga ASEM yaitu The Asia-Europe Foundation (ASEF) yang memiliki kapasitas dalam melaksanakan dan memprakarsai program kerjasama mobilitas tenaga kerja. ASEF didirikan pada tahun 1997, setahun setelah dimulainya ASEM. Itu adalah inisiatif dari para pemimpin Singapura dan Prancis, yang ditugaskan untuk melibatkan masyarakat sipil di seluruh anggota ASEM ke dalam proses antar wilayah. Tugasnya adalah mengelola kegiatan yang berada di bawah pilar ketiga kerjasama ASEM, yaitu budaya, intelektual, dan pertukaran antar orang. hingga saat ini, ASEF adalah satu-satunya lembaga ASEM. ASEF ini melibatkan pakar migrasi tenaga kerja dari pemerintah bersama dengan lembaga swadaya masyarakat, organisasi internasional, sektor swasta serta para akademisi dari dua benua. ASEF merancang insiatif dan juga saran kebijakan baru bersama dengan organisasi internasional yang aktif pada kebijakan mobilitas tenaga kerja di seluruh Asia dan Eropa diantaranya ILO dan International Organization for Migration (IOM) serta yayasan lain yang berfokus pada mobilitas tenaga kerja dan migrasi secara lebih umum dari dua benua. Tugas dan tanggungjawab mereka akan diserahkan ke kementerian terkait dari ASEM, khususnya otoritas imigrasi dan entitas sosial, ekonomi dan tenaga kerja dari Negara anggota, serta memiliki fungsi sebagai basis pengetahuan untuk kebijakan yang akan dibuat dalam konteks ASEM. ASEF mendukung dan menambah diskusi ASEM melalui pertukaran, konferensi dan aktivitas berbasis web lainnya dalam tema migrasi ASEM.

Dalam rangka bekerjasama di bidang keimigrasian, ASEF berkewajiban secara moral dan professional untuk melindungi dan meningkatkan kesehatan para migran, bekerjasama untuk pengembangan kebijakan nasional yang memberikan akses yang sama dalam hal layanan kesehatan dan sosial bagi para migran tanpa membeda-bedakan status mereka. Di Uni Eropa, mobilitas pekerja di seluruh wilayah Serikat terjamin oleh piagam sosial dan difasilitasi sejumlah proyek multilateral. Terkait warga non Uni Eropa, perjanjian bilateral dengan Negara-negara asal kembali menjadi instrument penting yang digunakan oleh Negara Uni Eropa untuk mengelola program imigrasi serta secara efektif mengatur pasar tenaga kerja. Sementara itu, di Asia perjanjian bilateral tentang migrasi tenaga kerja cukuo baru dan belum mampu terlihat sebagia contoh praktik 
Jurnal Sains Riset (JSR)

p-ISSN 2088-0952, e-ISSN 2714-531X

http://journal.unigha.ac.id/index.php/JSR

DOI. 10.47647/jsr.v10i12

yang baik. Adanya kerjasama keimigrasian ini mengakibatkan penurunan biaya perekrutan yang sebelumnya tinggi yang dikeluarkan oleh pekerja migran.

Adapun beberapa pertemuan yang dilakukan ASEM sebagai bentuk 70able70ama keimigrasian terlihat pada 70able dibawah ini:

Tabel 2 Pertemuan ASEM

\begin{tabular}{|c|c|c|}
\hline Waktu & Tempat & $\begin{array}{c}\text { Nama } \\
\text { Konferensi }\end{array}$ \\
\hline $\begin{array}{l}\text { 4-5 April } \\
2002\end{array}$ & $\begin{array}{l}\text { Lanzarote, } \\
\text { Spanyol }\end{array}$ & $\begin{array}{l}\text { Konferensi } \\
\text { Tingkat } \\
\text { Menteri ASEM } \\
\text { ke-1 tentang } \\
\text { Kerjasama } \\
\text { untuk } \\
\text { Manajemen } \\
\text { Arus Migrasi } \\
\text { antara Eropa } \\
\text { dan Asia }\end{array}$ \\
\hline $\begin{array}{l}10-12 \\
\text { Maret } 2003\end{array}$ & Denmark & $\begin{array}{l}\text { Konferensi } \\
\text { ASEM ke-1 } \\
\text { Direktur } \\
\text { Jenderal } \\
\text { Imigrasi dan } \\
\text { Manajemen } \\
\text { Arus Migrasi }\end{array}$ \\
\hline $\begin{array}{l}12 \\
\text { November } \\
2004\end{array}$ & $\begin{array}{l}\text { Beijing, } \\
\text { Cina }\end{array}$ & $\begin{array}{l}\text { Konferensi } \\
\text { ASEM ke-2 } \\
\text { Direktur } \\
\text { Jenderal } \\
\text { Imigrasi dan } \\
\text { Manajemen } \\
\text { Arus Migrasi } \\
\end{array}$ \\
\hline 2004 & $\begin{array}{l}\text { The } \\
\text { Hague, } \\
\text { Belanda }\end{array}$ & $\begin{array}{l}\text { Konferensi } \\
\text { ASEM ke-3 } \\
\text { Direktur } \\
\text { Jenderal } \\
\text { Imigrasi dan } \\
\text { Manajemen } \\
\text { Arus Migrasi }\end{array}$ \\
\hline
\end{tabular}

\begin{tabular}{|c|c|c|}
\hline $\begin{array}{l}25-26 \\
\text { Desember } \\
2005\end{array}$ & $\begin{array}{l}\text { Bali, } \\
\text { Indonesia }\end{array}$ & $\begin{array}{l}\text { Konferensi } \\
\text { ASEM ke-4 } \\
\text { Direktur } \\
\text { Jenderal } \\
\text { Imigrasi dan } \\
\text { Manajemen } \\
\text { Arus Migrasi }\end{array}$ \\
\hline $\begin{array}{l}11-12 \\
\text { Desember } \\
2006\end{array}$ & $\begin{array}{l}\text { Kuopio, } \\
\text { Finlandia }\end{array}$ & $\begin{array}{l}\text { Konferensi } \\
\text { ASEM ke-5 } \\
\text { Direktur } \\
\text { Jenderal } \\
\text { Imigrasi dan } \\
\text { Manajemen } \\
\text { Arus Migrasi }\end{array}$ \\
\hline $\begin{array}{l}19-26 \\
\text { November } \\
2007\end{array}$ & $\begin{array}{l}\text { Seoul, } \\
\text { Korea } \\
\text { Selatan }\end{array}$ & $\begin{array}{l}\text { Konferensi } \\
\text { ASEM ke-6 } \\
\text { Direktur } \\
\text { Jenderal } \\
\text { Imigrasi dan } \\
\text { Manajemen } \\
\text { Arus Migrasi }\end{array}$ \\
\hline $\begin{array}{l}17-18 \\
\text { November } \\
2009\end{array}$ & $\begin{array}{l}\text { Goa, } \\
\text { Prancis }\end{array}$ & $\begin{array}{l}\text { Konferensi } \\
\text { ASEM ke-7 } \\
\text { Direktur } \\
\text { Jenderal } \\
\text { Imigrasi dan } \\
\text { Manajemen } \\
\text { Arus Migrasi }\end{array}$ \\
\hline $\begin{array}{l}1-2 \\
\text { Desember } \\
2009\end{array}$ & Goa, India & $\begin{array}{l}\text { Konferensi } \\
\text { ASEM ke-8 } \\
\text { Direktur } \\
\text { Jenderal } \\
\text { Imigrasi dan } \\
\text { Manajemen } \\
\text { Arus Migrasi }\end{array}$ \\
\hline $\begin{array}{l}21-23 \\
\text { November } \\
2010\end{array}$ & Belgia & $\begin{array}{l}\text { Konferensi } \\
\text { ASEM ke-9 } \\
\text { Direktur } \\
\text { Jenderal } \\
\text { Imigrasi dan } \\
\text { Manajemen } \\
\text { Arus Migrasi } \\
\end{array}$ \\
\hline
\end{tabular}




\begin{tabular}{|c|c|c|}
\hline $\begin{array}{l}5-7 \\
\text { September } \\
2011\end{array}$ & Mongolia & $\begin{array}{l}\text { Konferensi } \\
\text { ASEM ke-10 } \\
\text { Direktur } \\
\text { Jenderal } \\
\text { Imigrasi dan } \\
\text { Manajemen } \\
\text { Arus Migrasi }\end{array}$ \\
\hline $\begin{array}{l}30-31 \\
\text { Oktober } \\
2012\end{array}$ & $\begin{array}{l}\text { Nicosia, } \\
\text { Siprus }\end{array}$ & $\begin{array}{l}\text { Konferensi } \\
\text { ASEM ke-11 } \\
\text { Direktur } \\
\text { Jenderal } \\
\text { Imigrasi dan } \\
\text { Manajemen } \\
\text { Arus Migrasi }\end{array}$ \\
\hline $\begin{array}{l}9-10 \\
\text { Oktober } \\
2013\end{array}$ & $\begin{array}{l}\text { Tokyo, } \\
\text { Jepang }\end{array}$ & $\begin{array}{l}\text { Konferensi } \\
\text { ASEM ke-12 } \\
\text { Direktur } \\
\text { Jenderal } \\
\text { Imigrasi dan } \\
\text { Manajemen } \\
\text { Arus Migrasi }\end{array}$ \\
\hline $\begin{array}{l}5-6 \\
\text { Oktober }\end{array}$ & Singapura & $\begin{array}{l}\text { Konferensi } \\
\text { ASEM ke-13 } \\
\text { Direktur } \\
\text { Jenderal } \\
\text { Imigrasi dan } \\
\text { Manajemen } \\
\text { Arus Migrasi }\end{array}$ \\
\hline $\begin{array}{l}28-29 \\
\text { September }\end{array}$ & Kamboja & $\begin{array}{l}\text { Konferensi } \\
\text { ASEM ke-14 } \\
\text { Direktur } \\
\text { Jenderal } \\
\text { Imigrasi dan } \\
\text { Manajemen } \\
\text { Arus Migrasi }\end{array}$ \\
\hline
\end{tabular}

\section{PENUTUP}

\section{Kesimpulan}

Salah satu bentuk kerjasama keimigrasian dalam ASEAN adalah dibuatnya ASEAN bebas visa (ASEAN Framework Agreement on Visa Exemption). Mayoritas Negara ASEAN turut menerapkan kebijakan tersebut tak terkecuali Indonesia. Indonesia berhasil meningkatkan jumlah wisatawan manca negara akibat diberlakukannya pengaturan kebijakan bebas visa, yang mana dasar hukumnya adalah Perpres No. 21/2016. Sementara itu, bentuk kerjasama keimigrasian ASEM adalah dengan satu-satunya lembaga bernama ASEF yang berkewajiban secara moral dan professional untuk melindungi dan meningkatkan kesehatan para migrant.

\section{Saran}

Perlu dipikirkan secara tegas mengenai cara mengawasi aspek keamanan negara karena keberadaan orang asing di Indonesia sebagai akibat dari pemberian bebas visa.

\section{UCAPAN TERIMA KASIH}

Ucapan terimakasi penulis ucapkan pada Ibu/Bapak .... selaku dosen pengampu mata kuliah kerjasama keimigrasian, juga pada para penulis sebelumnya yang karyakaryanya dijadikan referensi dalam penulisan ini, serta terimakasih kepada para pihak yang tidak bisa disebutkan satu persatu yang turut mendukung terlaksananya penelitian ini hingga selesai.

\section{DAFTAR PUSTAKA}

Abella, Manolo, August Gachter, and Juliet Tschank. A Triple Win in Migration: Ensuring Migrant Workers' Right to Protect All Workers. Singapore: AsiaEurope Foundation (ASEF), 2014.

Admin. "Pengawasan Kantor Imigrasi Surakarta Pada Warga Negara Asing Dalam Lalu Lintas MEA." Karyaedukasi. Last modified 2020. Accessed April 8, 2021. https://karyaedukasi.com/2020/12/12/p engawasan-kantor-imigrasi-surakartapada-warga-negara-asing-dalam-lalulintas-mea/.

Arifin, Ridwan. Proses Pemeriksaan Keimigrasian Di Bandara Internasional. Politeknik Imigrasi, 2019.

Damayanti, Ni Wayan Sri Ertami, and Ngakan Ketut Dunia. "Pengaturan 
Kebijakan Bebas Visa Kunjungan Dalam.” HAN FH Udayana (2017): 15 .

Direktorat Jenderal Imigrasi. Kerjasama Keimigrasian, 2021.

Erdian. Efektivitas Penerapan Kebijakan Bebas Visa Kunjungan Dikaitkan Dengan Selective Policy Keimigrasian Indonesia, 2018.

Foundation, Asia-Europe. "Health of Migrants in Asia and Europe." Beta Asef. Last modified 2020. Accessed April 10, 2021. https://beta.asef.org/projects/themes/pu blic-health/2478-health-and-migrationperspectives-from-asia-andeurope/2552-health-of-migrants-inasia-and-europe.

Indonesia, Kementerian Luar Negeri Republik. "Asian-Europe Meeting (ASEM).” Kemlu.Go.

International Organization for Migration. "The ASia-European Union Meeting's (ASEM) Conference of the Directors General of Immigration and Management of Migratory Flows." Iom.

Jazuli, Ahmad. "Implementasi Kebijakan Bebas Visa Dalam Perspektif Keimigrasian." Jurnal Ilmiah Kebijakan Hukum 10, no. 3 (2016): 211-225. https://ejournal.balitbangham.go.id/ind ex.php/kebijakan/article/view/179.

Kementerian Luar Negeri Republik Indonesia. "Asia-Europe Meeting (ASEM)." Kemlu.Go. Last modified 2018. Accessed April 8, 2021. https://kemlu.go.id/portal/id/read/154/h alaman_list_lainnya/asia-europemeeting-asem.

Khandekar, Gauri. Inter-Regional Relations and the Asia-Europe Meeting (ASEM). United Kingdom: Palgrave Macmillan,
2017.

Kristianto, Yohanes Ivan Adi. ASEAN Common Visa as the "ASEANSchengen": Future Perspectives to Develop Southeast Asia, 2019.

Lavenex, Flavia Jurje and Sandra. "EuropeAsia Connectivity." University of Geneva (n.d.).

Pinatih, Ni Komang Desy Arya. "ASEAN Framework Agreement on Visa Exemption and Transnational Crime: East Java Case Studies." IAFOR Journal of the Social Sciences 2, no. 2 (2016).

Rukajat, Ajat. Pendekatan Penelitian Kualitatif. Yogyakarta: Deepublish, 2018.

Sekretariat Nasional ASEAN. "Dirjen Imigrasi Se-ASEAN Bahas Soal Keimigrasian Di DGICM 2018.” Setnas Asean. Last modified 2017. Accessed April 8, 2021. http://setnasasean.id/news/read/dirjen-imigrasi-seasean-bahas-soal-keimigrasian-didgicm-2018.

Sitinjak, Silvya M J. "Kesepakatan ASEAN Tentang Keimigrasian Dalam Kerangka Masyarakat Ekonomi ASEAN (MEA) 2015 Dan Relevansinya Dengan Pengaturan Hukum Nasional Indonesia." Universitas Sumatera Utara, 2016.

Tim Ajar Kermakim. Kerjasama Keimigrasian. Politeknik Imigrasi, 2021.

Yulianto, Budi, Mohammad Maskan, and Alifiulahtin Utaminingsih. Metode Penelitian Bisnis. UPT Percetakan dan Penerbitan Polinema, 2018. 